\title{
Efektivitas Kompres Bawang Merah terhadap Nyeri Sendi pada Lansia
}

\author{
Siti Fadlilah ${ }^{1}$, Ririn Wahyu Widayati ${ }^{2}$ \\ ${ }^{1,2}$ Fakultas Ilmu Kesehatan, Universitas Respati Yogyakarta, Indonesia \\ Email: sitifadlilah@ respati.ac.id
}

\begin{abstract}
The effectiveness of Red Onion Compress on Joint Pain in the Elderly. One of the changes in the musculoskeletal system such as changes in muscles and joint bones is the most common among the elderly aged $>60$ years. The percentage of the joint pain among the elderly in the special region of Yogyakarta is $25.4 \%$. If not treated immediately the incidence rate of the joint disease will increase significantly. This can be overcome by providing an intervention in the form of onion compress. The result of a preliminary study indicated that 22 elderly people experienced the joint pain. The objective is to investigate the effectiveness of onion compress in the joint pain among the elderly in Sanggrahan Hamlet, Wedomartani, Ngemplak, Sleman, Yogyakarta. Research Method is this was a quantitative study, namely a quasi-experimental study. The sample consisted of 15 people. The sampling technique was the purposive sampling technique. The measurement instrument was the pain ratio scale. The statistical test was the Wilcoxon signed rank test. Results are The mean scores of the pain scale before and after onion compress were 5.2 and 2.4 with a mean difference of 2.8 . The bivariate test yielded $p$-value $=0.001$. Conclusion and Suggestion are Onion compress is effective to decrease the joint pain among the elderly in Sanggrahan Hamlet, Wedomartani, Ngemplak, Sleman, Yogyakarta. The respondents are expected to be able to apply an onion compress as a complementary therapy for the joint pain.
\end{abstract}

Keywords: Elderly, Joint pain, Onion compress

\begin{abstract}
Abstrak: Efektivitas Kompres Bawang Merah terhadap Nyeri Sendi pada Lansia. Salah satu perubahan sistem muskuloskletal seperti perubahan pada tulang otot dan sendi paling sering terjadi pada lansia memasuki usia $\geq 60$ tahun. Persentase nyeri sendi pada lansia di DIY yaitu 25,4\%. Jika tidak segera ditangani angka kejadian penyakit sendi akan meningkat secara signifikan. Hal tersebut dapat diatasi dengan memberikan intervensi berupa kompres bawang merah. Hasil studi pendahuluan didapatkan 22 lansia yang mengalami nyeri sendi. Tujuan yaitu mengetahui efektivitas kompres bawang merah terhadap nyeri sendi pada lansia di Dusun Sanggrahan Wedomartani Ngemplak Sleman Yogyakarta. Metode Penelitian kuantitatif dengan penelitian quasy eksperimen. Jumlah sampel 15 orang. Teknik pengambilan sampel purposive sampling. Alat ukur skala nyeri rasio. Uji statistik wilcoxon signed rank test. Hasil rata-rata skala nyeri sebelum dan sesudah kompres bawang merah adalah 5,2 dan 2,4 dengan selisih mean 2,8. Hasil uji bivariat didapatkan $p$-value 0,001. Kesimpulan dan saran yaitu kompres bawang merah efektif menurunkan nyeri sendi pada lansia di Dusun Sanggrahan Wedomartani Ngemplak Sleman Yogyakarta. Bagi responden diharapkan dapat menerapkan kompres bawang merah sebagai terapi komplemanter pada nyeri sendi.
\end{abstract}

Kata kunci: Kompres bawang merah, Lansia, Nyeri sendi

\begin{abstract}
Menurut Lukman dan Ningsih (2013), nyeri adalah suatu sensori yang tidak menyenangkan dari suatu emosional disertai kerusakan jaringan secara aktual maupun potensial atau kerusakan jaringan. Nyeri sendi terjadi akibat gangguan pada daerah sendi seperti deformitas pada sendi, dislokasi sendi, sublokasi sendi atau distrupsi struktur sekitar sendi.

Menurut World Health Organization pada tahun (2014), rheumatoid dan osteoarthritis dianggap menimbulkan beban tertinggi bagi pasien dibandingkan penyakit muskuloskeletal
\end{abstract}

lain. Saat ini diperkirakan paling tidak 355 juta penduduk dunia menderita rematik, artinya 1 dari 6 penduduk dunia mengalami penyakit nyeri sendi.

Menurut Riset Kesehatan Dasar Departemen Kesehatan Indonesia (2013), persentase penduduk lansia di atas $10 \%$ sekaligus paling tinggi ada di Provinsi DI Yogyakarta 13,04\%, Jawa Timur 10,40\% dan Jawa Tengah $10,34 \%$. Presentase nyeri sendi pada lansia di DIY yaitu $25,4 \%$ jika tidak segera ditangani angka kejadian penyakit sendi akan meningkat 
secara signifikan pada usia $\geq 50$ tahun dan prevalensi tertinggi terdapat pada kelompok usia $\geq 75$ tahun (Riset Kesehatan Dasar Departemen Kesehatan Indonesia, 2013). Hal tersebut bisa menyebabkan terjadinya penurunan aktivitas, isolasi sosial, gangguan tidur, dan depresi (Stanley dan Beare, 2012).

Penatalaksanaan nyeri sendi dapat dilakukan secara farmakologis dan nonfarmakologis. Menurut hasil penelitian Fadlilah (2017), terapi kompres air hangat juga berpengaruh pada penurunan nyeri sendidengan $p$-value 0,000 . Kompres hangat lain yang dapat dilakukan dengan menggunakan bawang merah. Bawang merah mengandung beberapa zat aktif yaitu allisin alin, flavonoid, alil profil disulfida, fitosterol, flavol, kalium, pectin, saponim dan tripropanal. Diantara beberapa zat aktif tersebut yaitu senyawa aktif flavonoid yang bersifat anti inflamasi atau anti radang. Senyawa aktif ini sangat berguna untuk membantu penyembuhan radang akibat luka memar, luka bakar, atau radang pada organ tubuh bagian dalam seperti radang sendi. Kuswardhani (2016), menyatakan dalam kandungan senyawa aktif bawang merah yaitu kaemferol mempunyai efek farmakologi sebagai analgesik. Menurut Rachmad, dkk (2012), bawang merah sering digunakan untuk kompres bawang merah.

Peneliti memilih Dusun Sanggrahan ini dikarenakan Dusun Sanggrahan sudah terdapat posyandu lansia yang baru didirikan pada bulan Maret 2017 oleh kader dusun Sanggrahan dan belum ada perlakuan farmakoterapi pada penderita nyeri sendi, dengan jumlah lansia 42 orang untuk yang berjenis kelamin laki-laki sebanyak 16 dan yang berjenis kelamin perempuan sebanyak 26 orang serta responden yang mengalami nyeri berjumlah 22 orang. Penanganan yang dilakukan pada kader biasanya lansia diberikan obat oleh pihak puskesmas dan tidak ada tindakan farmakoterapi. Para lansia mengatakan cara mengatasi nyerinya ada yang dengan beristirahat atau minum obat yang diberikan pihak puskesmas atau memberikan obat berbentuk krim. Berdasarkan data di atas peneliti tertarik untuk meneliti "Efektivitas Kompres Bawang Merah terhadap Nyeri Sendi pada Lansia di Dusun Sanggrahan Wedomartani Ngemplak Sleman Yogyakarta."

\section{METODE}

Metode Penelitian kuantitatif dengan penelitian quasy eksperimen. Rancangan penelitian yang digunakan adalah rancangan Pre
And Post Test Without Control (control diri sendiri). Rancangan penelitian yang digunakan adalah rancangan pre and post test without control. Jumlah sampel pada penelitian ini yaitu lansia sebanyak 15 orang. Teknik pengambilan sampel yang digunakan purposive sampling. Alat ukur yang digunakan yaitu skala nyeri numerik.

Analisa univariat pada penelitian ini menggunakan data numerik terdiri dari ukuran tendensi sentral dengan nilai mean, standar deviasi, standar error, maksimum dan minimum. Sedangkan analisa bivariat dalam penelitian ini digunakan untuk melihat perbedaan antara variabel dependen sebelum dan sesudah mendapatkan perlakuan dengan menggunakan Uji Shapiro-Wilk karena jumlah sampel kurang dari 50 pada uji normalitas ini dikatakan tidak normal karena nilai signifikan skala nyeri pre-test 0,001 sedangkan normal nilai kemaknaan $(p)>0,05$ karena data tidak berdistribusi normal maka digunakan uji wilcoxon. Jalannya penelitian di awali dengan tahap persiapan, pelaksanaan, dan tahap akhir.

\section{HASIL}

Tabel 1. Distribusi Frekuensi Berdasarkan Karakteristik Responden

\begin{tabular}{lrr}
\hline Karakteristik Responden & f & $\%$ \\
\hline Usia & & \\
$60-64$ & 11 & 93.3 \\
$\geq 65$ & 4 & 6,7 \\
\hline Jenis Kelamin & & \\
Laki-laki & 3 & 20,0 \\
Perempuan & 12 & 80,0 \\
\hline Pendidikan & & \\
SD & 10 & 66,7 \\
SMP & 3 & 20,0 \\
SMA & 2 & 13,3 \\
\hline Pekerjaan & & \\
Petani & 11 & 73,3 \\
IRT & 4 & 26,7 \\
\hline Total & 15 & 100 \\
\hline
\end{tabular}

Tabel 1 diketahui mayoritas lansia berusia 60-64 tahun yaitu sebanyak 14 orang (93,3\%). Mayoritas responden berjenis kelamin perempuan yaitu sebanyak 12 orang (80\%). Sebagian besar responden pendidikan SD yaitu sebanyak 10 orang $(66,7 \%)$. Sebagian besar lagi pekerjaan responden sebagai petani 11 orang $(73,3 \%)$. 
Tabel 2. Skala Nyeri Pre Test dan Post Test Pemberian Kompres Bawang Merah terhadap Nyeri Sendi Pada Lansia

\begin{tabular}{lccc}
\hline Nyeri Sendi & Min & Max & Mean \\
\hline Pre test & 3 & 6 & 5,2 \\
Post test & 1 & 4 & 2,4 \\
\hline
\end{tabular}

Tabel 2 diketahui bahwa rata-rata skala nyeri sendi responden sebelum diberikan kompres bawang merah yaitu 5,2 sedangkan ratarata skala nyeri sendi responden sesudah diberikan kompres bawang merah adalah 2,4.

Tabel 3. Usia dengan Skala Nyeri Pre Test dan Post Test Pemberian Kompres Bawang Merah terhadap Nyeri Sendi pada Lansia

\begin{tabular}{lccccc}
\hline \multirow{2}{*}{ Usia } & \multirow{2}{*}{} & \multicolumn{4}{c}{ Nyeri Sendi pretest-post test } \\
\cline { 3 - 6 } & & Min & Max & Mean & $\begin{array}{c}\text { Selisih } \\
\text { mean }\end{array}$ \\
\hline $60-64$ & 11 & $3-1$ & $6-4$ & $5,27-2$ & $-3,27$ \\
$\geq 65$ & 4 & $3-2$ & $6-4$ & $5-3$ & -2 \\
\hline
\end{tabular}

Tabel 3 diketahui bahwa rata-rata nilai tingkat nyeri usia 60-64 sebelum diberikan kompres bawang merah sebesar 5,27 sedangkan setelah diberikan kompres bawang merah 2 dengan penurunan sebesar 3,27 . Usia $\geq 65$ tahun rata-rata nilai tingkat nyeri sebelum diberikan kompres bawang merah yaitu 5 dan setelah diberikan kompres bawang merah yaitu 3 dengan penurunan sebesar 2,8 .

Tabel 4. Jenis Kelamin dengan Skala Nyeri Pre Test dan Post Test Pemberian Kompres Bawang Merah terhadap Nyeri Sendi pada Lansia

\begin{tabular}{lccccc}
\hline & & \multicolumn{4}{c}{ Nyeri Sendi pretest-post test } \\
\cline { 3 - 6 } JK & $\boldsymbol{\Sigma}$ & Min & Max & Mean & $\begin{array}{c}\text { Selisih } \\
\text { mean }\end{array}$ \\
\hline $\mathrm{L}$ & 3 & $5-2$ & $5-4$ & $5-3$ & -2 \\
$\mathrm{P}$ & 12 & $3-1$ & $6-4$ & $5,2-2,5$ & $-2,7$ \\
\hline
\end{tabular}

Tabel 4 diketahui rata-rata nilai tingkat skala nyeri pada jenis kelamin laki-laki sebelum diberikan kompres bawang merah yaitu 5 dan sesudah diberikan kompres bawang merah yaitu 3 dengan penurunan sebesar 2. Rata-rata nilai skala nyeri pada jenis kelamin perempuan sebelum diberikan kompres bawang merah yaitu 5,2 sedangkan setelah diberikan kompres bawang merah yaitu 2,5 dengan penurunan sebesar 2,7.
Tabel 5. Pendidikan dengan Skala Nyeri Pre Test dan Post Test Pemberian Kompres Bawang Merah terhadap Nyeri Sendi pada Lansia

\begin{tabular}{lccccc}
\hline \multirow{2}{*}{$\begin{array}{l}\text { Pendi- } \\
\text { dikan }\end{array}$} & $\boldsymbol{\Sigma}$ & \multicolumn{4}{c}{ Nyeri Sendi pre test-post test } \\
\cline { 3 - 6 } & & Min & Max & Mean & $\begin{array}{c}\text { Selisih } \\
\text { Mean }\end{array}$ \\
\hline SD & 10 & $3-1$ & $6-4$ & $5,1-2,1$ & -3 \\
SMP & 3 & $5-2$ & $6-3$ & $5,33-2,6$ & $-2,67$ \\
SMA & 2 & $5-3$ & $6-4$ & $5,5-3,5$ & -2 \\
\hline
\end{tabular}

Tabel 5 diketahui rata-rata nilai tingkat skala nyeri pada pendidikan SD sebelum diberikan kompres bawang merah yaitu 5,1 dan sesudah diberikan kompres bawang merah yaitu 2,1 dengan penurunan sebesar 3. Rata-rata nilai skala nyeri pendidikan SMP sebelum diberikan kompres bawang merah yaitu 5,33 sedangkan setelah diberikan kompres bawang merah yaitu 2,66 dengan penurunan sebesar 2,67. Untuk ratarata nilai skala nyeri pendidikan SMA sebelum diberikan kompres bawang merah yaitu 5,5 sedangkan setelah diberikan kompres bawang merah yaitu 3,5 dengan penurunan sebesar 2 .

Tabel 6. Pekerjaan dengan Skala Nyeri Pre Test dan Post Test Pemberian Kompres Bawang Merah Terhadap Nyeri Sendi pada Lansia

\begin{tabular}{lccccc}
\hline \multirow{2}{*}{$\begin{array}{l}\text { Peker- } \\
\text { jaan }\end{array}$} & $\boldsymbol{\Sigma}$ & \multicolumn{4}{c}{ Nyeri Sendi pre test-post test } \\
\cline { 3 - 6 } & Min & Max & Mean & $\begin{array}{c}\text { Selisih } \\
\text { Mean }\end{array}$ \\
\hline Petani & 11 & $3-1$ & $6-4$ & $5,27-2,45$ & $-2,82$ \\
IRT & 5 & $3-1$ & $6-3$ & $5-2,25$ & $-2,75$ \\
\hline
\end{tabular}

Tabel 6 diketahui rata-rata nilai tingkat skala nyeri pada pekerjaan petani sebelum diberikan kompres bawang merah yaitu 5,27 dan sesudah diberikan kompres bawang merah yaitu 2,45 dengan penurunan sebesar 2,82. Rata-rata nilai skala nyeri pada IRT sebelum diberikan kompres bawang merah yaitu 5 sedangkan setelah diberikan kompres bawang merah yaitu 2,25 dengan penurunan sebesar 2,75.

Tabel 7. Efektivitas Kompres Bawang Merah Terhadap Nyeri Sendi pada Lansia

\begin{tabular}{lccccc}
\hline $\begin{array}{l}\text { Nyeri } \\
\text { Sendi }\end{array}$ & Min & Max & Mean & $\begin{array}{c}\text { Selisih } \\
\text { mean }\end{array}$ & $\begin{array}{c}\boldsymbol{p} \text { - } \\
\text { value }\end{array}$ \\
\hline $\begin{array}{l}\text { Pre test } \\
\text { Post test }\end{array}$ & 3 & 6 & 5,2 & 2,8 & 0.001 \\
\hline
\end{tabular}

Tabel 7 diketahui bahwa rata-rata tingkat nyeri sendi sebelum diberikan kompres bawang merah adalah sebesar 5,2 sedangkan setelah 1 minggu diberikan terapi adalah sebesar 2,4 dengan penurunan 2,8. Hasil uji statistik menggunakan uji Wilcoxon didapatkan hasil p- 
value sebesar 0,001 karena p-value kurang dari 0,05 yang berarti kompres bawang merah efektif terhadap penurunan nyeri sendi responden yang telah diberikan intervensi selama 1 minggu atau 7 kali berturut-turut.

\section{PEMBAHASAN}

\section{Skala Nyeri Sebelum Diberikan Kompres Bawang Merah}

Berdasarkan tabel 2 diketahui bahwa ratarata nyeri sendi pada lansia di Dusun Sanggrahan Ngemplak Wedomartani Sleman Yogyakarta sebelum diberikan kompres bawang merah adalah sebesar 5,2 dimana rentang skala 5 masuk dalam skala nyeri sedang. Nyeri sendi merupakan gangguan pada daerah sendi seperti deformitas pada sendi, dislokasi sendi, sublokasi sendi atau distrupsi struktur sekitar sendi (Lukman dan Ningsih, 2013). Menurut Miller (2012), proses degeneratif mulai mempengaruhi tendon, ligamen, dan cairan sinovial dimana perubahan sendi pada lansia antara lain berkurangnya viskositas cairan synovial, penurunan kolagen dan sel elastin, kerusakan struktur fibrosa di jaringan ikat, gangguan perkembangan tulang rawan, pembentukan jaringan parut dan perubahan tulang rawan articular. Nyeri sendi pretest pada penelitian ini kondisi responden sedang beristirahat baik pagi, siang, sore, atau malam hari dengan kondisi duduk yaitu dilakukan pengukuran nyeri sendi 10 menit sebelum diberikan kompres bawang merah.

Nilai nyeri sendi pretest berdasarkan skala rasio, apabila ditinjau dari alat ukur yaitu skala nyeri numerik dengan nilai minimal nyeri sendi adalah 3 termasuk nyeri ringan, nilai maksimal yaitu 6 termasuk nyeri sedang dan rata-rata skala nyeri 5,2. Menurut Potter dan Perry (2013), faktor-faktor yang dapat mempengaruhi nyeri yaitu usia, jenis kelamin, kebudayaan, makna nyeri, perhatian, ansietas, keletihan, gaya koping dan dukungan keluarga dan sosial. Salah satu faktor yang mempengaruhi nyeri adalah usia.

Berdasarkan tabel 3 diketahui nilai mean pretest usia 60-64 tahun adalah 5,27 sedangkan usia $\geq 65$ tahun adalah 5 hasil tersebut menunjukan nilai mean skala nyeri pre-test usia 60-64 lebih tinggi di bandingkan $\geq 65$. Hal tersebut kemungkinan terjadi perbedaan persepsi dalam mengintprestasikan nyeri yang di rasakan. Menurut Potter dan Perry (2013), usia merupakan variabel penting yang mempengaruhi nyeri, seperti pada lansia dimana nyeri merupakan bagian dari proses penuaan yang tidak dapat dihindari. Setiap lansia dapat mengingat kejadian nyeri yang dialami berbeda dengan lansia yang mempunyai kelainan kognitif. Menurut Stanley dan Beare (2012), bahwa lansia yang usianya semakin tua biasanya kurang mampu untuk tetapi neuron tersebut tidak dapat mengalami regnerasi sehingga terjadinya kehilangan dan penyusutan neuron.Selain itu juga terjadinya penurunan pada aliran darah serebral, hal tersebut menyebabkan lansia mengalami penurunan intelektual.

Berdasarkan tabel 4 skala nyeri sebelum diberikan intervensi pada jenis kelamin perempuan skala nyeri paling tinggi yaitu skala 6 sedangkan laki-laki skala paling tinggi adalah 5 hasil menunjukan skala tertinggi pre-test yaitu jenis kelamin perempuan di bandingkan laki-laki. Menurut Potter dan Perry (2013), Hal ini menunjukkan perbedaan cara mempersepsikan sensasi nyeri pada setiap orang yaitu perbedaan faktor psikologis dan kognitif yang berinteraksi dengan faktor-faktor neurolofisiologis dalam mempersepsikan nyeri dimana perempuan cendrung mengalami ansietas sehingga persepsi menyadarkan individu dan mengartikan nyeri secara cepat dan kemudian individu dapat bereaksi terhadap nyeri yg dirasakan.

Selain itu menurut Stanley dan Beare (2012), faktor usia yang dapat meningkatkan terjadinya kehilangan unsur-unsur tulang yang terdiri dari penurunan hormon pada perempuan salah satunya hormon esterogen memainkan peran utama memperhatikan integritas tulang pada wanita. Hal tersebut disebabkan karena adanya hubungan antara umur perempuan dengan menopause yang menyebabkan hormon estrogen tidak berfungsi lagi, sementara itu salah satu fungsi hormon ini adalah untuk mempertahankan massa tulang. Hal ini terjadi pada masa usia 50-80 tahun dimana wanita mengalami penurunan hormon estrogen secara signifikan (Soeroso dkk, 2007). Kehilangan unsur-unsur tulang tejadi bila kadar esterogen turun akibat terjadinya menopause pada wanita sehingga wanita mempersepsikan lebih nyeri dibandingkan laki-laki pada keadaan ini hormon esterogen pada wanita tidak berfungsi lagi.

Menurut Suherry, Yusuf dan Indrawati (2016), salah satu fungsi hormon ini adalah untuk mempertahankan massa tulang apabila massa tulang berkurang maka sendi juga akan kehilangan fleksibilitasnya sehingga terjadi penurunan luas gerak sendi. Tidak menutup kemungkinan pria juga karena penyakit sendi merupakan penyakit degeneratif yang bisa menyerang pada segala jenis kelamin baik itu laki-laki maupun perempuan. Sehingga dapat disimpulkan skala nyeri pada perempuan lebih 
tinggi di pengaruhi oleh persepsi dan penurunan hormon esterogen akibat terjadinya menopause yang di alami perempuan pada usia 50-80 tahun.

Berdasarkan tabel 5 skala nyeri sebelum diberikan intervensi pada pendidikan dengan skala nyeri tertinggi pada pendidikan SD, SMP dan SMA yaitu skala 6. Hasil tersebut menunjukan skala tertinggi pretest pada pendidikan responden baik pada pendidikan SD, SMP dan SMA sama yaitu skala nyeri 6. Secara teori, kegagalan untuk mengobati rasa nyeri pada lansia seringkali terjadi bila edukasi pada penderita dan pendampingnya tidak cukup memadai. Pendidikan pada lansia dan pendampingnya dalam penatalaksanaan rasa nyeri sangat diperlukan untuk meningkatkan pengetahuan lansia tentang cara mengatasi nyerinya masing-masing, sehingga lansia yang kurang mengerti tentang pengobatan nyeri sendi hanya butuh diberikan edukasi Kasran \& Kusumaratna, (2006 dalam Lase, 2015).

Berdasarkan tabel 6 skala nyeri tertinggi pada pekerjaan petani dan IRT yaitu skala 6 . Hasil tersebut menunjukan skala tertinggi pre test pada pekerjaan petani dan IRT sama yaitu skala nyeri 6. Rasa sakit yang tiba-tiba biasanya disebabkan oleh aktivitas fisik berat atau tidak biasa. Keluhan nyeri akan lebih hebat sesudah mengadakan gerak badan atau bertambah dengan aktivitas dan bisa membaik dengan istirahat. Aktivitas fisik yang tidak tepat akan memperparah rasa sakit pada penderita nyeri sendi (Nahariani, Lismawati dan Wibowo, 2012).

Tingginya persentase yang bekerja di sektor pertanian antara lain terkait dengan tingkat pendidikan penduduk lansia yang pada umumnya masih rendah sehingga lapangan usaha sektor pertanian terbuka untuk semua kalangan dan tanpa prasyarat pendidikan. Seseorang yang melakukan gerakan yang sama secara terus menerus dalam waktu yang lama akan merasakan kelelahan fisik. Kelelahan ini timbul karena gerakan tubuh yang terus-menerus dan tanpa disadari mengakibatkan penurunan sistem otot (Boedhi, 2011). Lukman dan Ningsih (2013), menyatakan rentang gerak yang terbatas bisa disebabkan karena adanya deformitas skeletal, patologi sendi atau kontratur otot dan tendon sekitarnya sehingga pekerja petani kemungkinan besar mengalami nyeri sendi. Menurut Khoiri (2016), Penderita dengan gangguan nyeri sendi biasanya mengeluh nyeri pada waktu melakukan aktivitas, selain itu aktivitas fisik (terutama berlutut, jongkok, mengangkat, atau mendaki) juga dapat menyebabkan gangguan sendi sehingga mengakibatkan nyeri pada sendi.

\section{Skala Nyeri Sendi Lansia Sesudah Diberikan Intervensi Kompres Bawang Merah}

Berdasarkan tabel 3 skala nyeri usia $\geq 65$ tahun setelah diberikan intervensi nilai rata-rata yaitu 3 sedangkan usia 60-64 rata-rata 2. Hasil tersebut menunjukan nilai rata-rata post test usia 60-64 tahun mengalami penurunan sebanyak 3,27 dibandingkan usia $\geq 65$ yang mengalami penurunan 2 skala. Menurut Stanley dan Beare (2012) kecepatan absorpsi pada sistem muskuloskletal mengalami perlambatan seiring bertambahnya usia.

Menurut Anggraini (2013), Secara fisiologis dengan bertambahnya umur maka kemampuan organ-organ tubuh akan mengalami penurunan secara alamiah tidak terkecuali gangguan fungsi sendi. Dari hasil tersebut dapat disimpulkan semakin usia bertambah maka akan terjadinya penurunan sistem muskuloskletal mengakibatkan terjadinya nyeri pada sendi dan penurunan skala atau penyembuhan nyeri sendi terjadi lebih lama dari biasanya dikarenakan semakin tinggi usia, penyembuhan lebih lambat dibandingkan usia $<50$ tahun sehingga terjadi proses degeneratif pada sendi.

Berdasarkan tabel 4 rata-rata skala nyeri sendi setelah diberikan intervensi kompres bawang merah pada responden perempuan yaitu 2,5 sedangkan laki-laki rata-rata 3 . Hasil tersebut menunjukan penurunan skala nyeri post-test pada perempuan sebesar 2,7 sedangkan laki-laki mengalami penurunan 2 skala. Toleransi nyeri sejak lama telah menjadi subjek penelitian yang melibatkan pria dan wanita. Akan tetapi toleransi terhadap nyeri dipengaruhi oleh faktor-faktor biokimia dan merupakan hal yang unik pada setiap individu, tanpa memperhatikan jenis kelamin karena individu bereaksi terhadap nyeri dengan cara yang berbeda-beda dimana toleransi terhadap nyeri pada individu yaitu terdapat sesuatu ketidakinginan untuk menerima tingkat keparahan yang lebih tinggi dan durasi yang lebih lama (Potter dan Perry, 2013). Dapat ditarik kesimpulan pada hasil tabel 4 ini bahwa perempuan lebih cepat mengalami penurunan yang signifikan yang rendah karena ketika nyeri menyerang, perempuan lebih koperatif untuk menangani nyerinya dibandingkan laki-laki terbukti dari data penelitian ini perempuan mengalami penurunan skala lebih banyak dari pada laki-laki.

Berdasarkan tabel 5 rata-rata skala nyeri sendi setelah diberikan intervensi kompres bawang merah pada responden yang riwayat 
pendidikannya SD yaitu 2,1 SMP yaitu skala 2,66 sedangkan SMA skala 3,5. Hasil tersebut menunjukan penurunan skala nyeri post test pada pendidikan SD lebih banyak penurunan sebanyak 3 dibandingkan dengan tingkat pendidikan SMP dan SMA. Menurut Lase (2015), apa yang terjadi pada masyarakat lansia ini sebenarnya di sebabkan oleh kesadaran yang masih rendah. Begitu pula edukasi dan informasi sering kali salah dan tidak dimengerti. Salah satu faktor yang tak kalah penting adalah, gaya hidup yang salah Siswono, (2008 dalam Riyanto, 2010). Dapat disimpulkan bahwa riwayat pendidikan akhir lansia tidak dapat mempengaruhi besarnya insidensi nyeri sendi hanya saja lansia perlu diberikan edukasi terkait penanganan nyeri sendi dengan benar.

Berdasarkan tabel 6 skala nyeri maksimal setelah diberikan intervensi kompres bawang merah pada responden yang pekerjaan sebagai petani yaitu skala nyeri 4 dan IRT skala nyeri 3 . Hasil tersebut menunjukan bahwa skala nyeri post test pada pekerjaan sebagai petani lebih tinggi dibandingkan IRT. Menurut Khoiri (2016), para pekerja yang biasa dengan beban berat akan mempunyai risiko terserang gangguan sendi lebih besar dibandingkan dengan pekerja yang tidak mengangkat beban berat. Gangguan sendi ini biasanya mengenai sendi penopang berat badan misalnya pada panggul, lutut, vertebra, tetapi dapat juga mengenai bahu, sendi-sendi jari tangan, dan pergelangan kaki.

Pada penelitian Nahariani, Lismawati dan Wibowo (2012), sebagian besar responden yang mengalami intensitas nyeri berat adalah responden yang melakukan aktivitas fisik aktif. Hal ini menunjukkan bahwa aktivitas fisik aktif dapat menyebabkan meningkatnya intensitas nyeri sendi yang dirasakan oleh lansia karena aktivitas fisik dengan intensitas tinggi yang berlebihan dapat memberikan beban yang berlebihan pada sendi dan meningkatkan risiko cedera. Dapat disimpulkan pada penelitian ini bahwa pekerjaan sebagai petani sering mengalami nyeri sendi ketika selesai bekerja sehingga penurunan skala nyeri tidak dapat turun secara cepat ketika responden diberikan intervensi dikarenakan responden masih tetap bekerja sebagai petani setiap hari. Oleh karena itu pada lansia yang aktivitas fisiknya aktif dan mengalami nyeri sendi dianjurkan mengurangi sedikit aktivitasnya untuk menurunkan intensitas nyeri sendi yang dirasakan, meskipun diharapkan lansia tetap aktif dimasa tua tetapi harus disesuaikan dengan kemampuan fisiknya.

\section{Efektivitas Kompres Bawang Merah Terhadap Nyeri Sendi pada Lansia}

Berdasarkan tabel 2 diketahui bahwa ratarata skala nyeri sendi pada lansia di Dusun Sanggrahan Ngemplak Wedomartani Sleman Yogyakarta setelah diberikan intervensi kompres bawang merah yaitu 2,4. Menurut Mccaffery et al (1989 dalam Potter dan Perry, 2013), skala intensitas nyeri numerik 2 masuk dalam inteprestasi skala nyeri ringan. Dapat disimpulkan bahwa rata-rata lansia mengalami nyeri ringan setelah diberikan intervensi kompres bawang merah. Dari hasil penelitian ini menunjukan bahwa terjadi penurunan yang signifikan pada tingkat skala nyeri pada lansia di Dusun Sanggrahan Ngemplak Wedomartani Sleman Yogyakarta selama 7 kali berturut-turut (7 hari).

Kompres bawang merah memiliki pengaruh yang signifikan terhadap tingkat nyeri sendi setelah diberikan intervensi selama 7 kali berturut-turut. Keadaan tersebut membuktikan bahwa kompres bawang merah dapat menurunkan tingkat nyeri sendi pada lansia di Dusun Sanggrahan Ngemplak Wedomartani Sleman Yogyakarta. Kandungan bawang merah terdapat senyawa-senyawa turunan seperti senyawa alin yang berubah menjadi allisin, asam piruvat, dan ammonia karena adanya enzim allinase selain itu juga pada bawang merah terdapat kandungan flavonoid dan senyawa aktif berupa kaemferol yang mempunyai efek farmakologi sebagai antiinflamasi dan analgesik (Kuswardhani, 2016). Selain itu juga bawang merah mengandung allylcysteine sulfoxie (allin) dimana senyawa ini dapat menghasilkan panas dan sering digunakan untuk kompres. Hasil penelitian ini mendukung dengan penelitian Rachmad dkk (2012), bahwa panas bawang merah efektif menghangatkan tubuh dan menurunkan suhu tubuh hal tersebut dikarenakan bawang merah mempunyai kandungan allin yang menguap apabila tergerus.

Menurut Mohan (2012, dalam Lase 2015), menyatakan pada keadaan nyeri sendi pada daerah sinovium mengakibatkan terjadinya sinovitis dan pembentukan pannus yang akhirnya menyebabkan kerusakan pada sendi, kerusakan yang terjadi pada sel dan jaringan akan membebaskan berbagai mediator substansi radang. Asam arakhidonat mulanya merupakan komponen normal yang disimpan pada sel dalam bentuk fosfolipid dan dibebaskan dari sel penyimpanan lipid oleh asil hidrosilase sebagai respon adanya noksi. Asam arakidonat kemudian mengalami metabolisme menjadi dua alur. Alur 
siklooksigenase yang membebaskan prostalglandin, prostasiklin dan tromboksan. Prostalglandin yang dihasilkan melalui jalur siklooksigenase berperan dalam proses timbulnya nyeri, demam dan reaksi-reaksi peradangan.

Menurut Suherry, Yusuf dan Indrawati (2016) berpendapat bahwa dengan pemberian kompres bawang merah yang dicampur dengan minyak kelapa murni dimana minyak kelapa digunakan untuk membantu difusi kandungan bawang merah yang juga mempunyai senyawa aktif seperti kaemferol sebagai antiinflamasi dan analgesik. Kandungan kaemferol dan minyak kelapa akan berdifusi melalui permukaan kulit yaitu stratum korneum yang terletak dibawah epidermis melewati dermis dan masuk kedalam mikrosirkulasi kemudian zat tersebut masuk ke pembuluh darah yang ada di sendi sehingga menurunkan nyeri sendi yang muncul. Cara kerja dari kandungan kaemferol tersebut dengan menghambat enzim siklooksigenase yang dapat menurunkan sintesis prostaglandin sehingga mengurangi terjadinya vasodilatasi pembuluh darah dan aliran darah lokal yang menyebabkan migrasi sel radang pada area radang akan menurun karena kandungan kaemferol pada bawang merah. Dengan menurunnya sel radang pada area yang mengalami radang akan menyebabkan nyeri sendi yang muncul ikut berkurang.

Dari hasil wawancara yang didapatkan peneliti ada beberapa kekurangan dan kelebihan

\section{DAFTAR PUSTAKA}

Anggraini, N. E. 2013. Hubungan Obesitas dan Faktor-Faktor pada Individu yang Berkaitan dengan Kejadian Osteoarthritis Genu di Rumah Sakit Islam Surabaya. [Disertasi]. Surabaya: Departemen Epidemiologi Fakultas Kesehatan Masyarakat Universitas Airlangga.

Badan Penelitian Dan Pengembangan Kesehatan Kementerian Kesehatan RI. 2013. Riset Kesehatan Dasar. http://www.who.int/medicines/areas/priorit y_medicines/BP6_12Osteo.pdf?ua=1 (Diakses pada 22 September 2017).

Boedhi, D.R. 2011. Buku Ajar Geriatic (Ilmu Kesehatan Lanjut Usia). Edisi 4. Jakarta: Balai Penerbit FKUI.

Fadlilah, S. 2017. Pengaruh Kompres Jahe dan Kompres Air Hangat terhadap Tingkat Nyeri Sendi Lansia di Dusun Banjeng Maguwoharjo Depok Sleman Yogyakarta. Prosiding. ISSN 1907-3887. dari kompres bawang merah tersebut.Untuk kekurangan bawang merah rata-rata responden mengatakan bau dari bawang merah yang lama dan harus dicuci berkali-kali. Kelebihannya panas yang keluar dari bawang merah semakin lama semakin panas sehingga menyebabkan responden merasa lebih nyaman sehingga nyeri yang dirasakan responden dapat berkurang dan kelebihan yang lain responden yaitu bawang merah sangat mudah di dapatkan serta harganya yang terjangkau.

\section{SIMPULAN}

Berdasarkan hasil penelitian dapat disimpulkan bahwa kompres bawang merah efektif terhadap penurunan nyeri sendi padalansia di Dusun Sanggrahan Wedomartani Ngemplak Sleman Yogyakarta.

\section{SARAN}

Berdasarkan hasil penelitian diharapkan kompres bawang merah dapat digunakan sebaga salah satu terapi nonfarmakologi yang mudah dan murah untuk penanganan pertama nyeri sendi pada lansia. Peneliti lain diharapkan dapat mengembangkan penelitian dengan menggunakan kelompok kontrol ataupun dengan responden dari rentang usia remaja dan dewasa.

Khoiri, A. 2016. Faktor yang Menyebabkan Nyeri Sendi pada Lansia di UPT PSLU Kabupaten Magetan. Jawa Timur: Universitas Muhammadiyah Ponorogo. [Tesis]. Ponorogo: Fakultas Ilmu Kesehatan, Universitas Muhammadiyah Ponorogo.

http://eprints.umpo.ac.id/1916/2/BAB\%20 1.pdf (Diakses pada tanggal 29 Maret 2018).

Kuswardhani, D.S. 2016. Sehat Tanpa Obat Dengan Bawang Merah, Bawang Putih Seri Apotik Dapur. Yogyakarta: ANDI.

Lase, E.H. 2015. Pengaruh Kompres Jahe terhadap Intensitas Nyeri Pada Penderita Rheumathoid Arthritis Usia 40 Tahun Keatas di Lingkungan Kerja Puskesmas Tiga Balata. [Skripsi]. Universitas Sari Mutiara Indonesia. http://103.15.241.30/opac/uploaded_files/d 
okumen_isi/Monograf/130206157_001.pdf (Diakses pada 27 September 2017).

Lukman., dan Ningsih, N. 2013. Asuhan Keperawatan pada Klien dengan Gangguan Sistem Muskuloskletal. Jakarta: Salemba, Medika.

Miller, A. Carol. 2012. Nursing for Wellness in Older Adults Sixth Edition. China: Library of Congress Cataloging-in-Publication Data.

Nahariani, P., Lismawati, P., \& Wibowo, H. 2015. Hubungan antara Aktivitas Fisik dengan Intensitas Nyeri Sendi pada Lansia di Panti Werdha Mojopahit Kabupaten Mojokerto. Jurnal Metabolisme Vol. 2, No. 2 April 2013, 2(2).

Potter \& Perry. 2013. Buku Ajar Fundamental Keperawatan Edisi 4, Volume 2. Jakarta: EGC.

Fundamental Keperawatan, Edisi 4, Volume 1. Jakarta: EGC.

Rachmad, S. S., \& Gareso, P. L. 2012. Penentuan Efektifitas Bawang Merah dan Ekstrak Bawang Merah (Allium Cepa var. ascalonicum) dalam Menurunkan Suhu Badan. http://repository.unhas.ac.id/bitstre am/handle/123456789/3412/JURNAL\%20 RACHMAD.pdf (Diakses pada tanggal 9 Oktober 2017).

Riyanto, D. 2010. Hubungan Pengetahuan Sikap dan Prilaku tentang Nyeri pada Lansia di Posyandu Lansia Kusuma Desa Palur Mojolaban Sukoharjo. [Skripsi].
Surakarta: Fakultas Ilmu Kesehatan, Universitas Muhammadiyah Surakarta. http://eprints.ums.ac.id/10543/1/J1100500 11.pdf (Diakses pada tanggal 29 Maret 2018).

Soeroso, J. dkk. 2007. Buku Ajar Ilmu Penyakit Dalam Jilid II. Edisi IV. Jakarta: Pusat Penerbitan Departemen Ilmu Penyakit Dalam FKUI.

Stanley, M., \& Beare, P. G. 2012. Buku Ajar KG Perawatan Gerontik. (2nd ed). Jakarta: Penerbit Buku Kedokteran EGC.

Suherry, R., Yusuf, A., \& Indarwati, R. 2013. Pemberian Campuran Daun Pandan Wangi (Pandanus amaryllifolius roxb) dan Virgin Coconut Oil (VCO) Berpengaruh terhadap Penurunan Nyeri Sendi pada Lansia Dengan Osteoartritis (The Mixture of Fragrant Pandan's Leaves and Virgin Coconut Oil Reduce Joint Pain in Elderly with Osteoarthritis). Jurnal Departemen Keperawatan Jiwa Komunitas Unair. https://www.researchgate.net/publication/3 09134126_PENURUNAN_NYERI_SEND I_PADA_LANSIA_DENGAN_OSTEOA RTRITIS_The_Mixture_of_Fragrant_Pand an\%27s_Leaves_and_Virgin_Coconut_Oil _Reduce_Joint_Pain_in_Elderly_with_Ost eoarthritis (Diakses pada 26 Maret 2018).

World Health Organization. 2014. International Statistical Classification of Disease and Related Health Problems Tenth Revision Volume 2 second edition. Geneva: World Health Organization. 